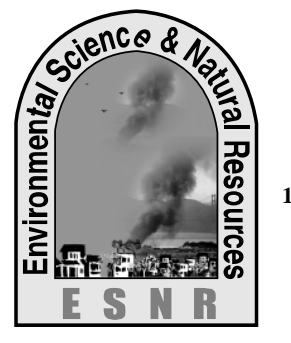

\title{
Heavy Metal Contamination in Water and Sediments of Passur River near the Sundarbans Mangrove of Bangladesh
}

\author{
S. C. Shil ${ }^{1}$, M. S. Islam ${ }^{1 *}$, A. Irin ${ }^{1}$, T. R. Tusher ${ }^{1}$ and M. E. Hoq ${ }^{2}$ \\ ${ }^{1}$ Department of Environmental Science and Resource Management, Mawlana Bhashani Science and \\ Technology University, Tangail-1902, \\ ${ }^{2}$ Bangladesh Fisheries Research Institute, Mymensingh-2201, Bangladesh \\ *Corresponding author: islammstazu@yahoo.com
}

\begin{abstract}
The study was conducted to investigate the heavy metal contamination in water, sediment and fishes from the Passur river in the Mongla port area near Sundarbans mangrove during the period from January to June 2013. The water samples were collected from five different sampling stations as St-1 (upstream- 1km upper from port area), St-2 (port area), St-3 (downstream-1 km lower from port area), St-4 (tributary) and St-5 (1 km lower from tributary). Sediment samples were collected monthly from Station-1, 2 and 3 during the study period. The concentrations of heavy metals $(\mathrm{Cu}, \mathrm{Zn}, \mathrm{Fe}$ and $\mathrm{Cr})$ in water were found from water much lower than the permissible level. The concentrations of five heavy metals $(\mathrm{Cr}, \mathrm{Cu}, \mathrm{Ni}, \mathrm{Pb}$ and $\mathrm{Fe}$ ) in the sediment samples were $\mathrm{Fe}$ at 23481.61 to $15339.4 \mathrm{mg} / \mathrm{kg}$, while other metals were much lower and found little difference among different months. The result indicated that passerious pollution in the Passur river is due to heavy metals; whereas the concentrations of elements found could mainly be attributed to geological sources. To maintain the sound environment and healthy ecosystem of the river and the surrounding areas, need proper management and monitoring of water quality of the river.
\end{abstract}

Key words: Heavy metal, Passur river, Water and Sediment

\section{Introduction}

Heavy metals such as copper, iron, chromium and nickel are essential since they play an important role in the biological systems, whereas cadmium and lead are non-essential metals, as they are toxic, even in trace amounts (Fernandes et al., 2008). For the normal metabolism of the fish, the essential metals must be taken up from water, food or sediment (Canli and Atli, 2003). These essential metals can also produce toxic effects when the metal intake is excessively elevated (Tuzen, 2003). Studies on heavy metals in rivers, lakes, fish and sediments have been a major environmental focus especially during the last decade (Fernandes et al., 2008; Ozturk et al., 2008; Pote et al., 2008; Praveena et al., 2008). Sediments are important sinks for various pollutants like pesticides and heavy metals play a significant role in the remobilization of contaminants in aquatic systems under favorable conditions and in interactions between water and sediment (Rashed, 2011). Bangladesh is one of the most polluted countries, which currently holds 1176 industries that discharge about 0.4 millions $\mathrm{m}^{3}$ of untreated waste to the rivers in a day (Rabbani and Sharif, 2005). The increasing urbanization and industrialization of Bangladesh have negative implications for water quality. The deterioration could be due to the release of easily oxidized industrial and municipal organic wastes directly into the rivers without any consideration of the environment (BCAS, 2004). Bangladesh has extensive water bodies that have a high potential for fisheries production which play an important role in the agro-based economics of Bangladesh by providing nutrition, increasing employment opportunities and earning foreign exchange (Mustafa and Brooks, 2009). The successful aquaculture depends on the quality of different water parameters (Rahman, 1992). The objective of the study was to investigate the heavy metal contamination in water and sediment from Passur river at Mongla port near the Sundarbans mangrove of Bangladesh.

\section{Materials and Methods}

\section{Study area}

The study was conducted to investigate the heavy metal contamination in water and sediments from the Passur river at Mongla port in the Sundarbans mangroves during the period from January to June 2013. Mongla port area is located at $48 \mathrm{~km}$ south of Khulna city. Mongla is situated on the confluence of the river Passur and Mongla at Mouza Selabunia, Rampul, Bagerhat. South of Khulna, the Bhairab or the Rupsa flows further south and is renamed as Passur near Chalna and falls into the Bay of Bengal flowing to the right of Trikona and Dubla islands. The river is joined by Mongla canal at about $32 \mathrm{~km}$ south from Chalna. Flowing further south the river meets the Shibsha at about $32 \mathrm{~km}$ north from its mouth and debouches into the sea keeping its original name Passur (Shil et al., 2014).

\section{Water sample collection and analysis}

The water samples were collected fortnightly from five different sampling stations as St-1, St-2, St-3, St-4 and St-5 for six month considered as dry (Jan-Mar) and wet season (Apr-Jun) both in high and low tide period. The heavy metals as Copper ( $\mathrm{Cu})$, Zinc $(\mathrm{Zn})$, Iron $(\mathrm{Fe})$ and Chromium $(\mathrm{Cr})$ in water were determined with the help of Atomic Absorption Spectrophotometer in the Regional Office of the Department of Environment (DoE), Khulna, Bangladesh.

\section{Sediment sample collection and analysis}

The sediment samples were collected from three sampling stations as St-1, St-2 and St-3 for six months. Sediment samples were air dried, sieved with 230 mesh $(600 \mu)$ stainless screens to separate larger particles and pebbles and digested with 4:1 mixture of nitric acid. The samples were analyzed by AES in SGS India Limited, Kolkata-700034, India, in order to determine the heavy metals as Chromium $(\mathrm{Cr})$, Copper $(\mathrm{Cu})$, Nickel $(\mathrm{Ni})$, Lead $(\mathrm{Pb})$ and Iron $(\mathrm{Fe})$ in sediment. 


\section{Results and Discussions}

\section{Heavy metal in water}

In dry season, the concentration of $\mathrm{Cu}$ was 0.036 and $0.028 \mathrm{mg} / \mathrm{l}$, respectively at low and high tide in January; 0.023 and $0.026 \mathrm{mg} / \mathrm{l}$, respectively at low and high tide in February; and 0.026 and $0.013 \mathrm{mg} / \mathrm{l}$, respectively at low and high tide in March; where the highest values of $\mathrm{Cu} 0.036 \mathrm{mg} / \mathrm{l}$ at low tide and the lowest $0.013 \mathrm{mg} / \mathrm{l}$ at high tide were found in both January and March,

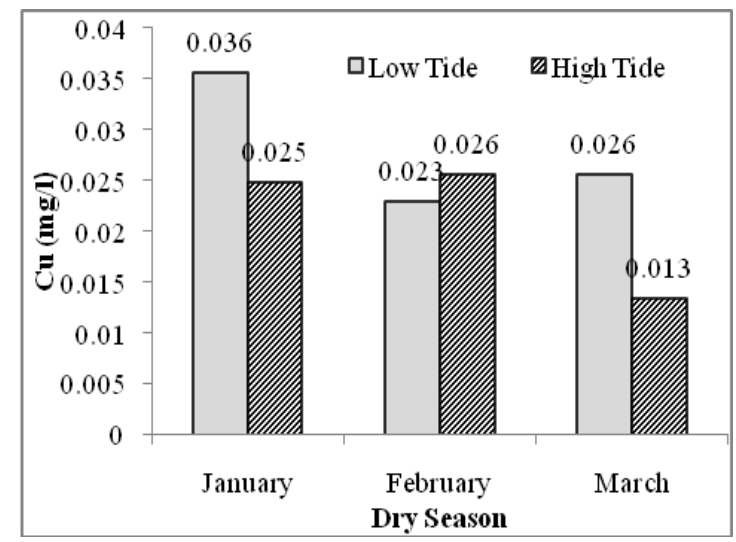

respectively (Fig. 1). The highest concentration of $\mathrm{Cu}$ was $0.02 \mathrm{mg} / \mathrm{l}$ at low tide and the lowest $0.01 \mathrm{mg} / \mathrm{l}$ at high tide in wet season were found in both April and May, respectively (Fig. 1). All the values of $\mathrm{Cu}$ in the wet season were within the standard limit of $1.0 \mathrm{mg} / \mathrm{l}$ (ECR, 1997). Islam and Gnauck (2009) found that all of the values (range from 0.03 to $0.19 \mathrm{mg} / \mathrm{l}$ ) were in considerable limit of pollutants.

Fig. 1. The concentration of $\mathrm{Cu}$ at dry and wet season in the water of Passur river

The highest concentrations of $\mathrm{Zn} 0.027 \mathrm{mg} / \mathrm{l}$ at high tide and the lowest $0.01 \mathrm{mg} / \mathrm{l}$ at low tide were found in both January and March, respectively (Fig. 2). The highest content of Zn $0.01 \mathrm{mg} / \mathrm{l}$ and the lowest $0.001 \mathrm{mg} / \mathrm{l}$ were

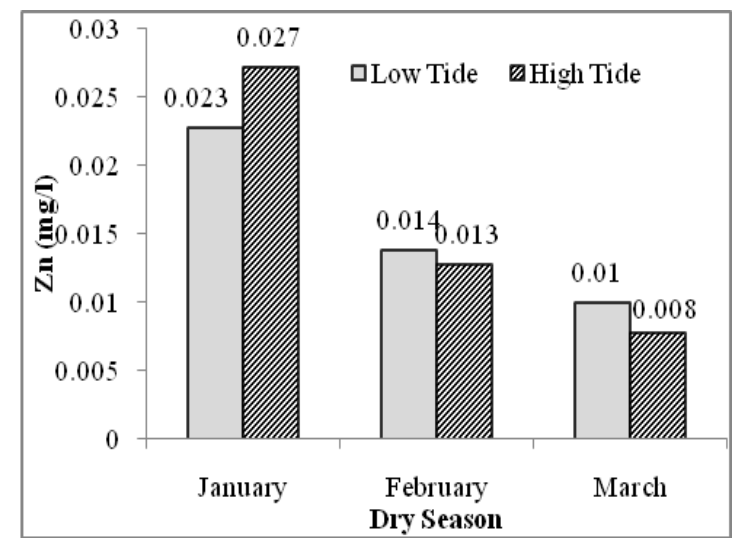

found at low tide during April and June (Fig. 2). The concentration of $\mathrm{Zn}$ in wet season was in the acceptable limit (>0.005 mg/l). So the water can be used for all purposes.

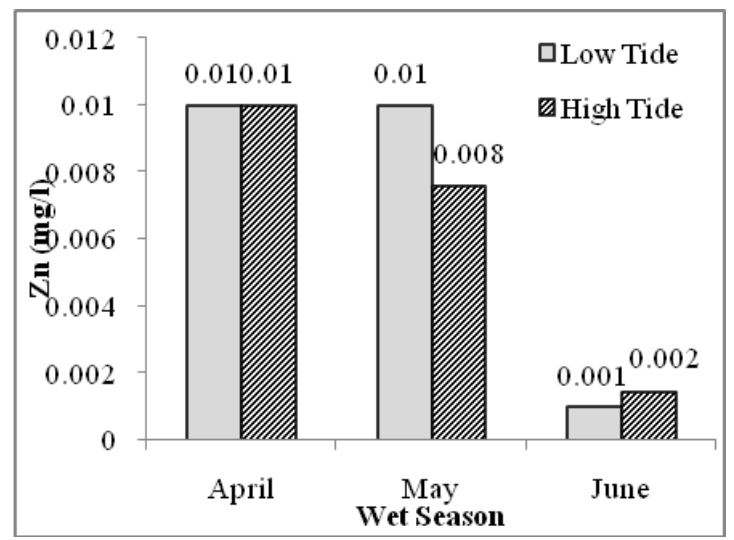

Fig. 2. The concentration of $\mathrm{Zn}$ at dry and wet season in the water of Passur river

In dry season, the content of Fe in January, February and March were $0.327,0.321$ and $0.321 \mathrm{mg} / \mathrm{l}$ at low tide and $0.347,0.324$ and $0.344 \mathrm{mg} / \mathrm{l}$ at high tide, respectively. The highest value of Fe $0.347 \mathrm{mg} / \mathrm{l}$ at high tide and the lowest $0.321 \mathrm{mg} / \mathrm{l}$ at low tide were found in January and February respectively (Fig. 3). In the wet season, the highest content of Fe $0.34 \mathrm{mg} / \mathrm{l}$ at high tide and the lowest $0.02 \mathrm{mg} / \mathrm{l}$ at both high and low tide was found in May and June respectively (Fig. 3). The study showed that the Fe concentration in both dry and wet season was within the acceptable limit $(0.3 \mathrm{mg} / \mathrm{l})$ except in June. So the river water could be used for all purposes. 

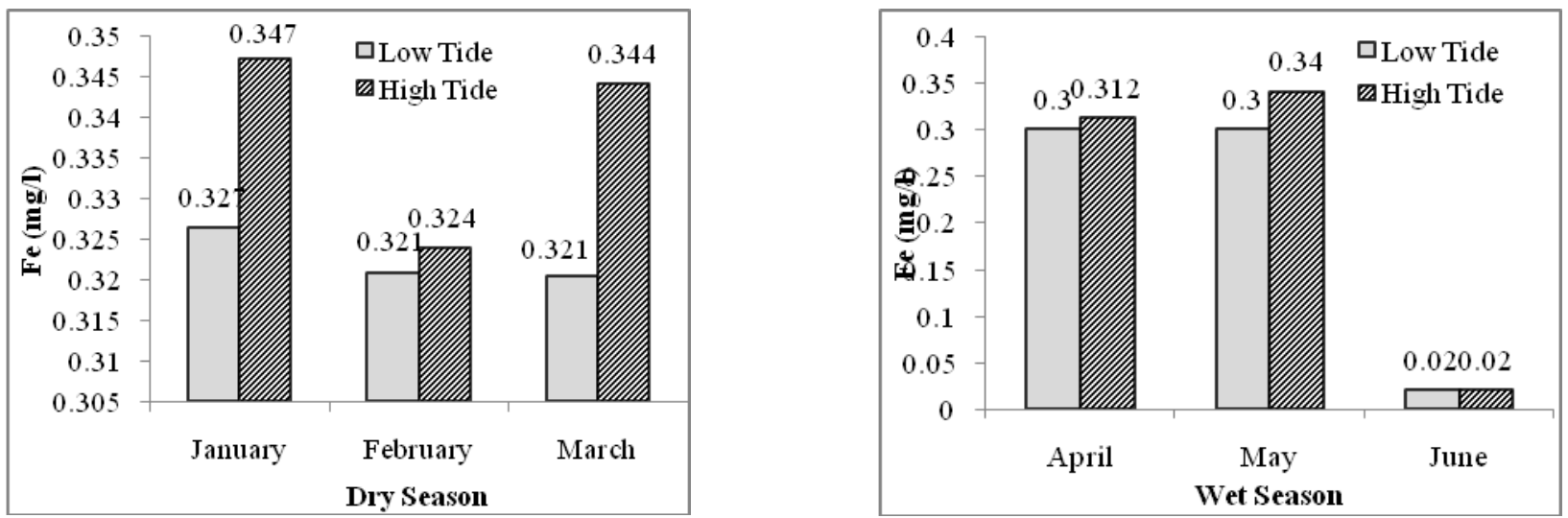

Fig. 3. The concentration of Fe at dry and wet season in the water of Passur river

Chromium salts are used in industrial processes and enter into the water bodies through discharges of industrial waste effluents. The $\mathrm{Cr}$ concentration in water

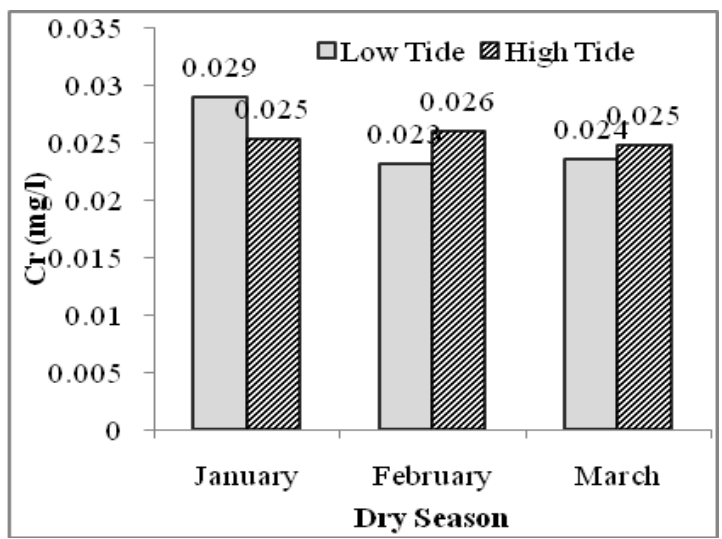

during both dry and wet season was in the acceptable limit $(0.05 \mathrm{mg} / \mathrm{l})$.

Fig. 4. The concentration of $\mathrm{Cr}$ at dry and wet season in the water of Passur river.

The comparative study between the heavy metal concentrations in water of Passur river and other rivers of Bangladesh such as Karnafuli, Buriganga, Shitalakhya, Balu and Turag rivers was performed to depict the metallic pollution status of Passur river in relation to others (Table 1). The study observed similar level of $\mathrm{Cu}$ concentration $(0.02 \mathrm{mg} / \mathrm{l})$ in water of Passur, Buriganga and Shitalakhya rivers, whereas Turag inhibiting higher $\mathrm{Cu}$ concentration. No $\mathrm{Cu}$ concentration was detected in Karnafuli river, while $0.01 \mathrm{mg} / \mathrm{l} \mathrm{Cu}$ was detected in Balu river water. The highest concentration of $\mathrm{Zn}$ was found in Turag river $(0.14 \mathrm{mg} / \mathrm{l})$ followed by Buriganga $(0.08 \mathrm{mg} / \mathrm{l})$, Balu (0.04 mg/l), Shitalakhya (0.02 mg/l) and Passur (0.01

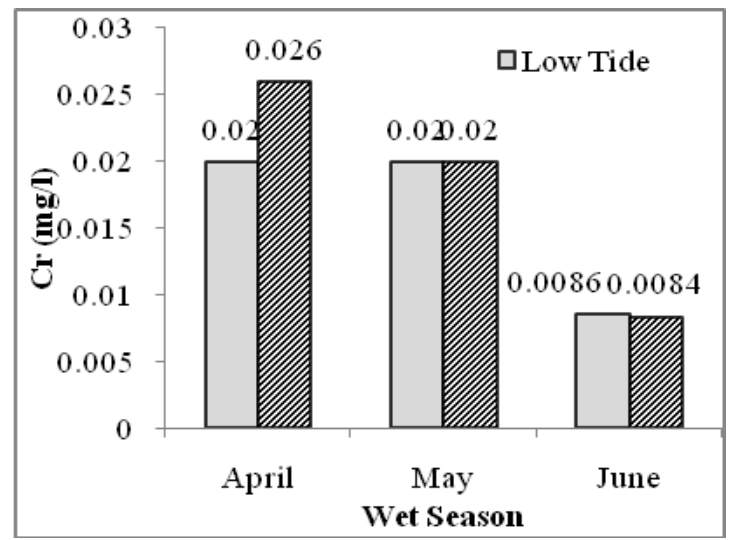

$\mathrm{mg} / \mathrm{l})$ river. Higher concentration of $\mathrm{Fe}$ was observed in Turag $(2.22 \mathrm{mg} / \mathrm{l})$ and Karnafuli $(1.23 \mathrm{mg} / \mathrm{l})$ rivers, whereas lower concentration was found in others including Passur river $(0.27 \mathrm{mg} / \mathrm{l})$. The highest $(25.97$ $\mathrm{mg} / \mathrm{l})$ and lowest $(0.02 \mathrm{mg} / \mathrm{l})$ concentration of $\mathrm{Cr}$ was found in Balu and Passur river, respectively, while similar level of $\mathrm{Cr}$ was observed in Buriganga (4.36 $\mathrm{mg} / \mathrm{l})$ and Shitalakhya $(4.77 \mathrm{mg} / \mathrm{l})$. It is clear from the overall analysis that Passur and Karnafuli rivers are in better state with lower level of heavy metal concentration than the other rivers, while Turag and Balu is suffering from heavy $\mathrm{Fe}$ and $\mathrm{Cr}$ load, respectively (Table 1).

Table 1. Comparison of heavy metal concentrations $(\mathrm{mg} / \mathrm{l})$ in water among the Passur, Karnafuli, Buriganga, Shitalakhya, Balu and Turag rivers of Bangladesh

\begin{tabular}{lcccccc}
\hline $\begin{array}{l}\text { Heavy } \\
\text { metals } \\
(\mathrm{mg} / \mathrm{l})\end{array}$ & $\begin{array}{c}\text { Karnafuli river } \\
\text { (Mamun } \text { et al., }\end{array}$ & $\begin{array}{c}\text { Buriganga } \\
\text { river (Azim } \text { et } \\
\text { al., 2009) }\end{array}$ & $\begin{array}{c}\text { Shitalakhya } \\
\text { river (Islam } \text { et } \\
\text { al., 2008) }\end{array}$ & $\begin{array}{c}\text { Balu river } \\
\text { (Islam } \text { et al., } \\
\text { 2012a) }\end{array}$ & $\begin{array}{c}\text { Turag river } \\
\text { (Islam } \text { et al., } \\
\text { 2012b) }\end{array}$ & $\begin{array}{c}\text { Passur river } \\
\text { (Present study) }\end{array}$ \\
\hline $\mathrm{Cu}$ & $\mathrm{Nd}$ & 0.02 & 0.02 & 0.01 & 0.07 & 0.02 \\
$\mathrm{Zn}$ & $\mathrm{Nt}$ & 0.08 & 0.02 & 0.04 & 0.14 & 0.01 \\
$\mathrm{Fe}$ & 1.23 & 0.07 & 0.01 & 0.02 & 2.22 & 0.27 \\
$\mathrm{Cr}$ & $\mathrm{Nd}$ & 4.36 & 4.77 & 25.97 & $\mathrm{Nt}$ & 0.02 \\
\hline
\end{tabular}

Note: $\mathrm{Nd}=$ Not detected; $\mathrm{Nt}=$ Not tested 


\section{Heavy metal in sediments}

Anthropogenic metals emission into the atmosphere such as $\mathrm{Pb}, \mathrm{Hg}, \mathrm{Zn}, \mathrm{Cd}$ and $\mathrm{Cu}$ are 1:3 orders of magnitude higher than natural fluxes. Sediment also serves as reservoir for pollutants and therefore a potential source of pollutants to the water column, organisms, and ultimately human consumers of those organisms (Issa, 2008). The concentration of $\mathrm{Cr}$ was observed 18.907, 15.083, 20.603, 19.957, 20.877 and $20.787 \mathrm{mg} / \mathrm{kg}$ in January to June, respectively. The concentration of $\mathrm{Cu}$ was found $6.333,7.110,19.350$, 21.310, 20.603 and $20.287 \mathrm{mg} / \mathrm{kg}$ in January, February, March, April, May and June, respectively. The concentration of $\mathrm{Ni}$ was observed 20.053, 19.590,
20.740, 20.860, 21.390 and $21.057 \mathrm{mg} / \mathrm{kg}$ in January, February, March, April, May and June, respectively. The concentration of $\mathrm{Pb}$ was observed 1.035, 1.110, $6.480,8.980,11.710$ and $12.200 \mathrm{mg} / \mathrm{kg}$ in January, February, March, April, May and June respectively. The concentration of Fe was found 19006.067, 19922.200, 22580.100, 21600.737, 21779.063 and $22947.993 \mathrm{mg} / \mathrm{kg}$ in January, February, March, April, May and June, respectively. The results of the sediments study indicated that a general absence of serious pollution in the Passur river was due to heavy metals, whereas the concentrations of elements found could mainly be attributed to geological sources.

Table 2. Heavy metal concentration in sediments from the Passur river at Mongla port area

\begin{tabular}{cccccc}
\hline Months & \multicolumn{5}{c}{ Heavy metal in sediments $(\mathrm{mg} / \mathrm{kg})$} \\
\cline { 2 - 5 } & $\mathrm{Cr}$ & $\mathrm{Cu}$ & $\mathrm{Ni}$ & $\mathrm{Pb}$ & $\mathrm{Fe}$ \\
\hline Jan. & 18.907 & 6.333 & 20.053 & 1.035 & 19006.067 \\
Feb. & 15.083 & 7.110 & 19.590 & 1.110 & 19922.200 \\
Mar. & 20.603 & 19.350 & 20.740 & 6.480 & 22580.100 \\
Apr. & 19.957 & 21.310 & 20.860 & 8.980 & 21600.737 \\
May & 20.877 & 20.603 & 21.390 & 11.710 & 21779.063 \\
Jun. & 20.787 & 20.287 & 21.057 & 12.200 & 22947.993 \\
Mean & 19.369 & 15.832 & 20.615 & 6.919 & 21306.030 \\
\hline
\end{tabular}

The comparative study between the heavy metal concentrations in sediments of the Passur river and other rivers such as Karnafuli, Buriganga, Shitalakhya and Turag river was also done to identify the pollution status of the studied rivers of Bangladesh in relation to sediment quality according to the EPA guideline for sediments quality (EPA, 1977). The study revealed that the Passur river is not polluted by $\mathrm{Cr}$ as it contains $19.37 \mathrm{mg} / \mathrm{kg} \mathrm{Cr}$ in sediment. On the other hand, Shitalakhya and Buriganga are heavily polluted with $\mathrm{Cr}$, while Karnafuli and Turag is moderately polluted (Table 3). However, Passur and Karnafuli rivers are in better state with standard $\mathrm{Cu}$ concentration, while moderate pollution load is observed in Buriganga, Shitalakhya and Turag rivers. The study found that all the rivers including Passur is in moderate state of pollution when considered $\mathrm{Ni}$ concentration, while higher concentration of $\mathrm{Ni}(200.45 \mathrm{mg} / \mathrm{kg})$ was observed in Buriganga river which indicating heavy $\mathrm{Ni}$ pollution. The $\mathrm{Pb}$ concentration in sediments exhibited that all the rivers except Buriganga re in non-pollution state, whereas moderate $\mathrm{Pb}$ pollution is detected in Buriganga river. Though available data on $\mathrm{Fe}$ concentration in sediments of Buriganga, Shitalakhya and Turag rivers were not found, much higher concentration of $\mathrm{Fe}$ was found in sediments of Passur and Karnafuli rivers which indicating that these two rivers are heavily polluted by Fe (Table 3 ). From the overall analysis, it can be stated that Passur river is in better state with standard heavy metal concentration except $\mathrm{Fe}$ than the other rivers compared in this study.

Table 3. Comparison of heavy metal concentrations $(\mathrm{mg} / \mathrm{kg})$ in sediments among the Karnafuli, Buriganga, Shitalakhya, Turag and Passur rivers of Bangladesh

\begin{tabular}{|c|c|c|c|c|c|c|c|c|}
\hline \multirow[t]{2}{*}{$\begin{array}{l}\text { Heavy } \\
\text { metals }\end{array}$} & \multirow{2}{*}{$\begin{array}{c}\text { Karnafuli } \\
\text { river (Mamun } \\
\text { et al., 2013) }\end{array}$} & \multirow{2}{*}{$\begin{array}{l}\text { Buriganga } \\
\text { river } \\
\text { (Ahmed et } \\
\text { al., 2010) }\end{array}$} & \multirow{2}{*}{$\begin{array}{c}\text { Shitalakhya } \\
\text { river (Islam et } \\
\text { al., 2014) }\end{array}$} & \multirow{2}{*}{$\begin{array}{c}\text { Turag river } \\
\text { (Banu et al., } \\
\text { 2013) }\end{array}$} & \multirow{2}{*}{$\begin{array}{l}\text { Passur } \\
\text { river } \\
\text { (Present } \\
\text { study) }\end{array}$} & \multicolumn{3}{|c|}{$\begin{array}{c}\text { EPA guideline for } \\
\text { sediments (EPA, 1977) }\end{array}$} \\
\hline & & & & & & NP & MP & HP \\
\hline $\mathrm{Cr}$ & 28.17 & 101.20 & 78.16 & 43.02 & 19.37 & $<25$ & $25-75$ & $>75$ \\
\hline $\mathrm{Cu}$ & 20.05 & 27.85 & 45.64 & 50.40 & 15.83 & $<25$ & $25-50$ & $>50$ \\
\hline $\mathrm{Ni}$ & 29.80 & 200.45 & 37.77 & $\mathrm{Nt}$ & 20.62 & $<20$ & $20-50$ & $>50$ \\
\hline $\mathrm{Pb}$ & 15.49 & 69.75 & 24.84 & 32.78 & 6.92 & $<40$ & $40-60$ & $>60$ \\
\hline $\mathrm{Fe}$ & 24075.00 & $\mathrm{Nt}$ & $\mathrm{Nt}$ & $\mathrm{Nt}$ & 21306.03 & $<1.7$ & $1.7-2.5$ & $>2.5$ \\
\hline
\end{tabular}

Note: $\mathrm{Nt}=$ Not tested, $\mathrm{NP}=$ Not polluted, $\mathrm{MP}=$ Moderately polluted, $\mathrm{HP}=$ Heavily polluted

\section{Conclusions}

The results of the study concluded that the Passur river is in good state with lower level of heavy metal contamination but higher level of Fe concentration in sediments which could mainly be attributed to geological and industrial sources. In this regard, to maintain the water and sediment qualities, and aquatic life of the river as well as the mangroves need proper 
monitoring and management though the prior initiative to be taken by the government authorities.

\section{References}

Ahmed, M. K.; Islam, S.; Rahman, M. S.; Haque, M. R. and Islam, M. M. 2010. Heavy metals in water, sediment and some fishes of Buriganga River, Bangladesh. International Journal of Environmental Research, 4(2): 321-332.

Azim, M. A.; Quraisi, S. B. and Islam, R. 2009. Impact of dumping untreated waste water on water quality of the river Buriganga, Bangladesh. Dhaka University Journal of Science, 57(1): 101-106.

Banu, Z.; Chowdhury, M. S. A.; Hossain, M. D. and Nakagami, K. 2013. Contamination and ecological risk assessment of heavy metal in the sediment of Turag river, Bangladesh: An index analysis approach. Journal of water Resource and Protection, 5: 239-248.

Canli, M. and Atli, G. 2003. The relationships between heavy metal $(\mathrm{Cd}, \mathrm{Cr}, \mathrm{Cu}, \mathrm{Fe}, \mathrm{Pb}, \mathrm{Zn})$ levels and the size of six Mediterranean fish species. Environmental Pollution, 121: 129-136.

EPA (Environmental Protection Agency). 1977. Guidelines for the Pollutional classification of Great Lakes harbor sediments. US Environmental Protection Agency, Region V, April 1977.

Fernandes, C., A.; Fontaínhas-Fernandes, D. C. and Salgado, M. A. 2008. Heavy metals in water, sediment and tissues of Liza saliens from Esmoriz-Paramos lagoon, Portugal. Environmental Monitoring Assessment, 136: 267275.

Islam, M. M.; Rahman, S. L.; Ahmed, S. U. and Haque, M. K. I. 2014. Biochemical characteristics and accumulation of heavy metals in fishes, water and sediments of the river Buriganga and Shitalakhya of Bangladesh. Journal of Asian Scientific Research, 4(6): 270-279.

Islam, M. S.; Tusher, T. R.; Mustafa, M. and Mahmud, S. 2012b. Effects of solid waste and industrial effluents on water quality of Turag river at Konabari industrial area, Gazipur, Bangladesh. Journal of Environmental Science and natural Resources, 5(2): 213-218.

Islam, M. S. N. and Gnauck, A. 2009. Threats to the Sundarbans mangrove wetland ecosystems from transboundary water allocation in the Ganges basin: A preliminary problem analysis. Int. J. Ecol. Econ. Stat., 13: 64-78.

Islam, M. Z.; Azim, M. A.; Islam, R. and Quraisi, S. B. 2008. Seasonal variation of heavy metals in water samples from Shitalakhya river. Journal of Bangladesh Academy of Science, 32(1): 13-22.

Islam, M. Z.; Noori, A.; Islam, R.; Azim, M. A. and Quraisi, S. B. 2012a. Assessment of the contamination of trace metal in Balu river water, Bangladesh. Journal of Environmental Chemistry and Ecotoxicology, 4(14): 242-249.

Issa, B. R.; Arimoro, F. O.; Ibrahim, M.; Birma, G. J. and Fadairo, E. A. 2008. Assessment of sediment contamination by heavy metals in River Orogodo (Agbor, Delta State, Nigeria). Current World Environment, 6(1): 29-38.

Mamun, A.; Sumon, K. A.; Sukhan, Z. P.; Hoq, E.; Alam, M. W.; Haq, M. S; Rashid, F. and Rashid, H. 2013. Heavy metal contamination in water and sediments of the river Karnafuli from south-east coast of Bangladesh. Conference paper, $4^{\text {th }}$ the International Conference on Environmental Aspects of Bangladesh, at Fukuoka, Japan. pp. 113-116.

Mustafa, M. G. and Brooks, A. C. 2009. A comparative study of two seasonal flood plain aquaculture systems in Bangladesh. Water Policy, 11(1): 69 79.

Ozturk, M. G.; Ozozen, O.; Minareci and Minareci, E. 2008. Determination of heavy metals in of fishes, water and sediment from the Demirkopru Dam Lake (Turkey). Journal of Applied Biological Sciences, 2(3): 99-104.

Pote, J.; Haller, L.; Loizeau, J. L.; Bravo, A. G.; Sastre, V. and Wildi, W. 2008. Effects of a sewage treatment plant outlet pipe extension on the distribution of contaminants in the sediments of the Bay of Vidy, Lake Geneva, Switzerland. Bioresource Technology, 99: 7122-7131.

Praveena, S. M.; Radojevic, M.; Abdullah, M. H. and Aris, A. Z. 2008. Application of sediment quality guidelines in the assessment of mangrove surface sediment in Mengkabong lagoon, Sabah, Malaysia. Iranian Journal of Environmental Health Science Engineering, 5(1): 35-42.

Rabbani, G. and Sharif, M. I. 2005. Dhaka City-State of Environment (SoE) 2005. UNEP in collaboration with BCAS and DoE, $40 \mathrm{p}$.

Rahman, M. S. 1992. Water quality management in aquaculture. BRAC Prokashana, Bangladesh, 84 p.

Rashed, M. N. 2011. Monitoring of environmental heavy metals in fish from Nasser Lake. Environmental International, 27: 27-33.

Tuzen, M. 2003. Determination of heavy metals in fish samples of the Mid Dam Lake Black Sea (Turkey) by graphite furnace atomic absorption spectrometry. Food Chemistry, 80: 119-123. 